\title{
Recovery copper and tin from a complex Oxide Copper Ore
}

\author{
Chuanfa Cui ${ }^{1,2, a}$, Shuming Wen ${ }^{1,2, b^{*}}$, Yawei Liu ${ }^{3, c}$ andYijie Wang ${ }^{1,2, d}$ \\ ${ }^{1}$ State Key Laboratory of Complex Nonferrous Metal Resources Clean Utilization, Kunming \\ University of Science and Technology, Kunming 650093, China \\ ${ }^{2}$ Faculty of Land Resource Engineering, Kunming University of Science and Technology, Kunming \\ 650093, China \\ ${ }^{3}$ Yunnan Hualian Zn-In Shares Co., Ltd Wenshan 663000, China \\ accf99999@126.com, bshmwen@126.com(Corresponding Author), \\ c907947582@qq.com, dyjwang2012@126.com
}

Keywords: Copper; Grinding Size; Flotation.

\begin{abstract}
The test study, the use of re-election - flotation processes can be efficiently recover copper, tin, sulfur, comprehensive utilization of resources to achieve the purpose. From ore analysis, the mine oxidation rate, up $43.46 \%$, is a copper oxide; active copper is high, reaching $20.03 \%$; other metals iron, lead and zinc content is high, is relatively refractory ore. Due to high rate of oxidation, serious mud after grinding, and ore contains a large number of mica, mica mineral mud and entrained in the foam, coupled with active copper, high impurity content, especially in the lead is the coexistence of a variety of lead mineral is difficult to suppress copper concentrate quality is difficult to improve.
\end{abstract}

\section{Introduction}

In natural resources, it is an important metal tin, silver and white, shiny, chemical stability, corrosion resistance, low toxicity, good ductility. Many important properties of tin malleability, ductility and corrosion resistance, etc. so that tin has a variety of uses. Currently, the tin more applications in the chemical, metal fabrication, decoration, etc. [2]. Tin of applications covering almost strategic emerging industries, therefore, tin is an important mineral resource development of strategic emerging industries, particularly those with significant strategic value in military, aviation, atomic energy field, tin. Tin choose other main method is to re-election and flotation. In reselection size has an important effect on the sorting effect, for coarse-grained disseminated ore sorting good effect, and for fine grade ore sorting difficulty increases [2]. The test study, the use of re-election flotation processes can be efficiently recover copper, tin, sulfur, comprehensive utilization of resources to achieve the purpose. The purpose of this study was to test the availability of qualified copper concentrate at the same time, as much as possible the recovery of tin minerals to achieve efficient utilization of mineral resources.

\section{Materials}

After grinding ore $-0.074 \mathrm{~mm} 60 \%$ of copper, tin and copper mine dissociation situation, coarse grain size tin. $+0.2 \mathrm{~mm}$ Grade: chalcopyrite-based monomer, but less, the amount of sulfur and copper combination of micro, small amount of oxygen-copper combination; seen cassiterite monomer. 0.2-0.074mm level: chalcopyrite-based monomer, but less, veins of copper, sulfur and copper combination of micro amount of oxygen copper has monomer dissociation, less; cassiterite most have monomer dissociation, pulse tin, iron, tin and tin phases combined copper objects less of ore phase analysis results are shown in table 2 and Table 3. 
Table 1 The Mult-elements analysis material

\begin{tabular}{lllllll}
\hline Components & $\mathrm{Cu}$ & $\mathrm{Sn}$ & $\mathrm{S}$ & $\mathrm{Fe}$ & $\mathrm{As}$ & $\mathrm{Zn}$ \\
\hline Wt $(\%)$ & 0.619 & .0654 & 7.32 & 34.27 & 0.559 & 0.996 \\
Components & $\mathrm{Pb}$ & $\mathrm{Wo}$ & $\mathrm{K}$ & $\mathrm{P}$ & $\mathrm{Ca}$ & $\mathrm{Mg}$ \\
Wt $(\%)$ & 0.893 & 0.042 & 0.71 & 0.092 & 16.80 & 7.20 \\
\hline
\end{tabular}

From Table 1, it is a more typical complex polymetallic ores, valuable elements which are mainly tin, copper, lead, zinc, iron and sulfur.

Table 2 Copper phase analysis of material

\begin{tabular}{cccccc}
\hline Projiect & $\begin{array}{c}\text { Free } \\
\text { copper } \\
\text { oxide }\end{array}$ & $\begin{array}{c}\text { Conjunction } \\
\text { oxidized copper }\end{array}$ & $\begin{array}{c}\text { Secondary } \\
\text { copper } \\
\text { sulphide }\end{array}$ & $\begin{array}{c}\text { Primary } \\
\text { copper } \\
\text { sulfide }\end{array}$ & $\begin{array}{c}\text { Total } \\
\text { copper }\end{array}$ \\
\hline Content(\%) & 0.13 & 0.12 & 0.13 & 0.22 & 0.61 \\
Occupancy(\%) & 21.81 & 20.03 & 21.65 & 36.51 & 100 \\
\hline
\end{tabular}

As can be seen from Table 2, copper ore oxidation rate was higher, accounting for $43.46 \%$. It increases the difficulty of the flotation recovery of copper minerals in the ore.

Table 3 Tin phase ananlysis of material

\begin{tabular}{cccc}
\hline Projiect & $\begin{array}{c}\text { Acid molten } \\
\text { tin }\end{array}$ & $\begin{array}{l}\text { cassite } \\
\text { rite }\end{array}$ & Total tin \\
\hline Content $(\%)$ & 0.06 & 0.59 & 0.65 \\
Occupancy $(\%)$ & 9.48 & 90.52 & 100.00 \\
\hline
\end{tabular}

As can be seen from Table 3, the vast majority of tin ore cassiterite, and its distribution was $90.52 \%$, followed by acid-soluble tin tin, distribution rate of $9.48 \%$. Thus, the recovery of tin ore minerals, should give priority to the re-election.

Results and discussion

According to the nature of the sample analysis, test focuses on the recovery of tin and copper minerals. In order to reduce the impact of the oxide and sulfide mineral collecting tin for re-election. Test program for the flotation of useful minerals tentatively re-sorting of copper sulfide, re-election process for the recovery of tin float heavy joint process. The grinding fineness is separated from copper and tin copper tin achieve key, the grinding fineness is determined both to give full consideration tin, copper minerals monomer dissociation, but also to minimize over crushed tin, tin reduce losses and facilitate re-election effective recovery equipment. Removal of sulfur compounds selected from tin impurities is crucial. Since this type of ore containing a large amount of sulfide and its large density, single-use re-election can not be removed, so we must re-election before the flotation desulfurization, in order to obtain good quality tin concentrates and tin higher recoveries. 


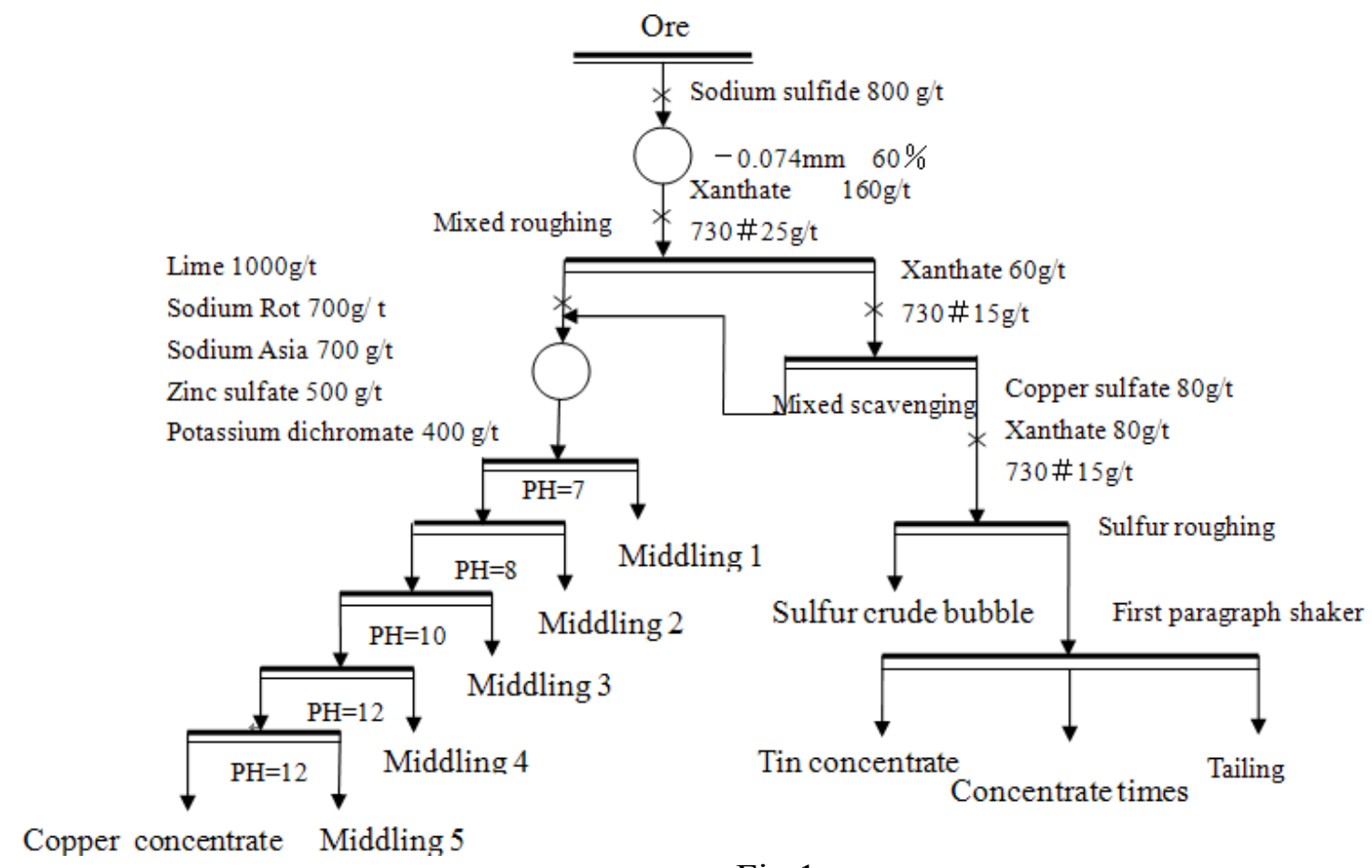

Fig 1

The results of the first group (Some wear not add sodium sulfide)

\begin{tabular}{|c|c|c|c|c|c|c|c|}
\hline \multirow{2}{*}{ Products } & \multirow{2}{*}{ Yield \% } & \multicolumn{2}{|c|}{ Cu } & \multicolumn{2}{c|}{ Sn } & \multicolumn{2}{c|}{ S } \\
\cline { 3 - 8 } & & Grade\% & Recovery \% & Grade \% & Recovery \% & Grade \% & Recovery \% \\
\hline Copper concentrate & 3.32 & $\mathbf{2 . 5 3 2}$ & $\mathbf{1 4 . 9 6}$ & 0.114 & 0.53 & 53.96 & 22.31 \\
\hline Middling 5 & 2.88 & 2.317 & 11.92 & 0.116 & 0.47 & 50.06 & 18.36 \\
\hline Middling 4 & 1.61 & 1.886 & 5.39 & 0.128 & 0.29 & 39.91 & 8.13 \\
\hline Middling 3 & 1.61 & 0.916 & 2.62 & 0.177 & 0.40 & 15.91 & 3.24 \\
\hline Middling 2 & 3.48 & 0.669 & 4.14 & 0.219 & 1.06 & 9.85 & 4.35 \\
\hline Middling 1 & 15.51 & 0.617 & 17.05 & 0.286 & 6.17 & 13.00 & 25.61 \\
\hline Sulfur crude bubble & 2.68 & 0.571 & 2.72 & 0.270 & 1.00 & 5.31 & 1.80 \\
\hline Some tin concentrates & 1.02 & 0.198 & 0.36 & $\mathbf{2 9 . 2 0}$ & $\mathbf{4 1 . 2 9}$ & 2.364 & 0.31 \\
\hline $\begin{array}{c}\text { Concentrate period of } \\
\text { time }\end{array}$ & 17.97 & 0.331 & 10.60 & 1.207 & 30.19 & 3.29 & 7.51 \\
\hline Paragraph tailings & 49.92 & 0.340 & 30.24 & 0.268 & 18.60 & 1.322 & 8.38 \\
\hline Total & 100 & 0.561 & 100 & 0.719 & 100 & 7.88 & 100 \\
\hline
\end{tabular}

The results of the second group

\begin{tabular}{|c|c|c|c|c|c|c|c|}
\hline \multirow{2}{*}{ Products } & \multirow{2}{*}{ Yield \% } & \multicolumn{2}{|c|}{ Cu } & \multicolumn{2}{|c|}{ Sn } & \multicolumn{2}{c|}{ S } \\
\cline { 3 - 8 } & Grade $\%$ & Recovery \% & Grade \% & Recovery \% & Grade \% & Recovery \% \\
\hline concentrates & 6.03 & $\mathbf{3 . 8 4}$ & $\mathbf{3 4 . 9 3}$ & 0.097 & 0.84 & 51.70 & 38.86 \\
\hline Middling 5 & 1.32 & 2.295 & 4.58 & 0.091 & 0.17 & 44.16 & 7.28 \\
\hline Middling $_{4}$ & 0.92 & 1.745 & 2.42 & 0.116 & 0.15 & 34.00 & 3.90 \\
\hline Middling $_{3}$ & 1.11 & 1.022 & 1.71 & 0.184 & 0.29 & 17.61 & 2.44 \\
\hline Middling 2 & 3.82 & 0.780 & 4.49 & 0.184 & 1.01 & 12.74 & 6.07 \\
\hline Middling & 13.34 & 0.511 & 10.28 & 0.320 & 6.12 & 11.64 & 19.34 \\
\hline $\begin{array}{c}\text { Sulfur crude } \\
\text { bubble }\end{array}$ & 3.18 & 0.726 & 3.48 & 0.287 & 1.31 & 9.47 & 3.75 \\
\hline $\begin{array}{c}\text { Some tin } \\
\text { concentrates }\end{array}$ & 2.22 & 0.276 & 0.92 & $\mathbf{1 9 . 4 9}$ & $\mathbf{6 2 . 1 4}$ & 5.33 & 1.48 \\
\hline $\begin{array}{c}\text { Concentrate } \\
\text { period of time }\end{array}$ & 16.60 & 0.364 & 9.11 & 0.502 & 11.95 & 3.32 & 6.87 \\
\hline Paragraph tailings & 51.46 & 0.362 & 28.08 & 0.217 & 16.02 & 1.564 & 10.01 \\
\hline Total & 100 & 0.663 & 100 & 0.697 & 100 & 8.03 & 100 \\
\hline
\end{tabular}

The experimental flow sheet was shown in fig 2 


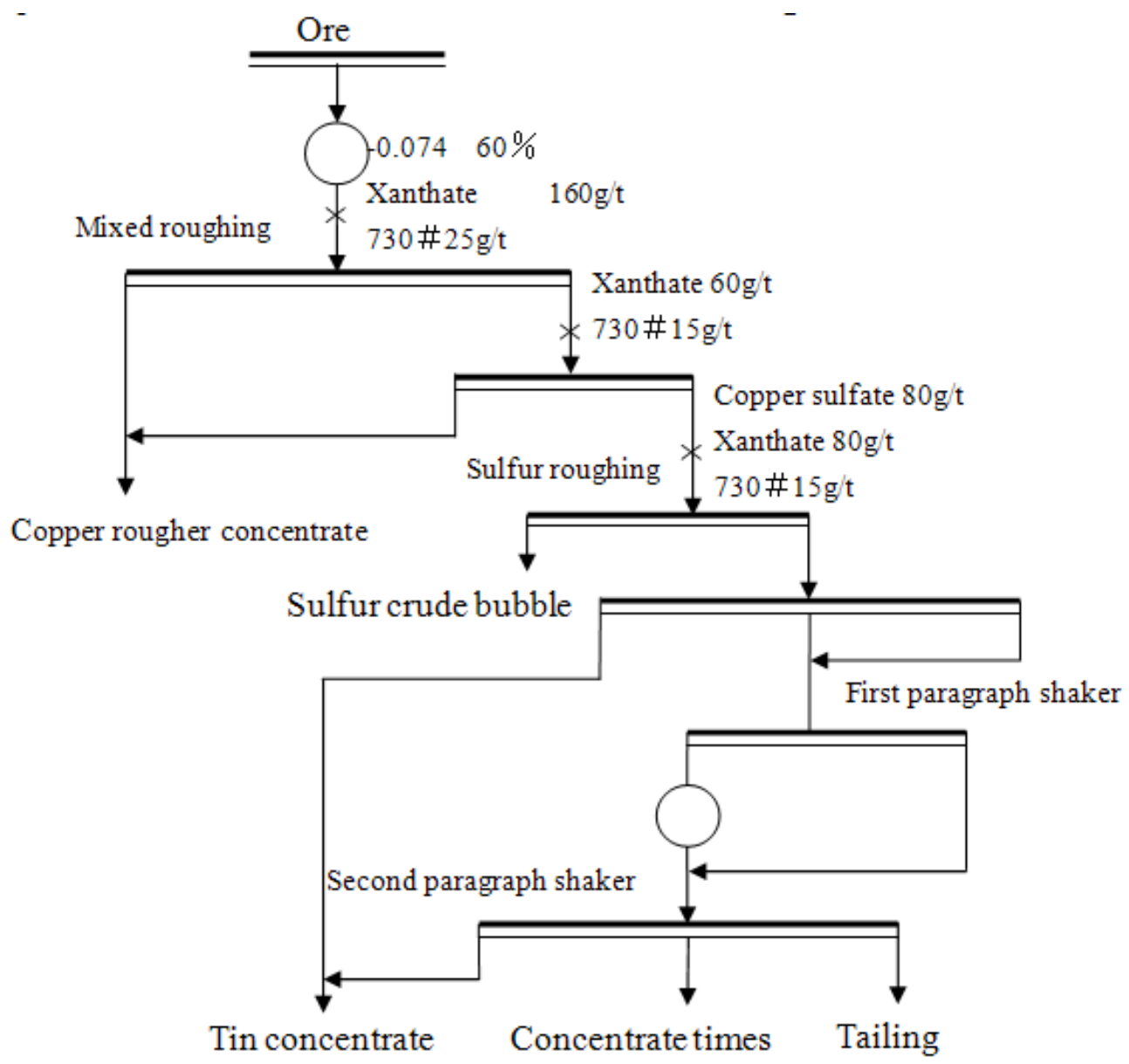

The results of the second group

Fig 2

\begin{tabular}{|c|c|c|c|c|c|c|c|}
\hline \multirow{2}{*}{ Products } & \multirow{2}{*}{ Yield \% } & \multicolumn{2}{|c|}{ Cu } & \multicolumn{2}{c|}{ Sn } & \multicolumn{2}{c|}{ S } \\
\cline { 3 - 8 } & & Grade $\%$ & Recovery $\%$ & Grade \% & Recovery \% & Grade \% & Recovery \% \\
\hline $\begin{array}{c}\text { Copper rougher } \\
\text { concentrate }\end{array}$ & 23.83 & 1.426 & 56.14 & 0.196 & 6.20 & 26.03 & 82.39 \\
\hline $\begin{array}{c}\text { Sulfur crude } \\
\text { bubble }\end{array}$ & 4.13 & 0.555 & 3.79 & 0.310 & 1.70 & 4.48 & 2.46 \\
\hline Tin concentrate & 3.09 & 0.280 & 1.43 & $\mathbf{1 7 . 9 0}$ & $\mathbf{7 3 . 3 7}$ & 6.50 & 2.67 \\
\hline Concentrate times & 23.78 & 0.317 & 12.45 & 0.235 & 7.41 & 1.892 & 5.98 \\
\hline Tailings & 45.17 & 0.351 & 26.19 & 0.189 & 11.32 & 1.083 & 6.50 \\
\hline Total & 100 & 0.605 & 100 & 0.754 & 100 & 7.53 & 100 \\
\hline
\end{tabular}

\section{Conclusions}

(1) From ore analysis, the mine oxidation rate, up $43.46 \%$, is a copper oxide; active copper is high, reaching $20.03 \%$; other metals iron, lead and zinc content is high, is relatively refractory ore.

(2) Due to high rate of oxidation, serious mud after grinding, and ore contains a large number of mica, mica mineral mud and entrained in the foam, coupled with active copper, high impurity content, especially in the lead is the coexistence of a variety of lead mineral is difficult to suppress copper concentrate quality is difficult to improve. Such as by current production process and reagent system, it is difficult copper concentrate output of qualified products.

(3) For tin, after flotation selected impurity into the shaker tin, you can get a better indicators of crude tin concentrates. 


\section{References}

[1] Joda NN, Rashchi F. Recovery of ultra fine grained silver and copper from PC board scraps. Sep Purif Technol. 2012;92:36.

[2] Hanafi J, Jobiliong E, Christiani A, Soenarta DC, Kurniawan J, Irawanc J. Material recovery and characterization of PCB from electronic waste. Proc Soc Behav Sci. 2012;57:331.

[3] Amer AM. Processing of copper anodic-slimes for extraction of valuable metals. Waste Manag. 2003;23(8):763.

[4] Lepetic V M .Cassiterite flotation:a review [ C] .In:Somasundaran P ed.Advances in Mineral Processing.Littleton: SME, 1986, 343 350.

[5]TIAN Zhong -cheng. Cassiterite Flotation[ M] , ( in Chi-nese). Beijing : Metallurgy Industry Press, 1990, 1. 